\title{
Memperkuat Lokalitas Kota Semarang di Era Globalisasi melalui Diplomasi Lokal
}

\author{
Hermini Sustianingsih, Nadia Farabi, Satwika Paramasatya \\ \& Sheiffi Puspapertiwi
}

Universitas Diponegoro

\begin{abstract}
Abstrak
Globalisasi menyebabkan semua lini kehidupan menjadi saling berhubungan. Desentralisasi yang dikuatkan melalui penyebaran nilai-nilai demokrasi melalui fenomena globalisasi nyatanya telah memunculkan pemerintah daerah sebagai salah satu aktor penting dalam hubungan internasional melalui perannya dalam paradiplomasi. Diadopsi dari pengalaman negara-negara maju, negara berkembang kini mengadaptasikan paradiplomasi dengan kondisi dan kepentingan yang dimiliki. Penelitian ini bertujuan untuk mengidentifikasi diplomasi yang kompatibel dengan konsep lokalitas, sehingga dapat memperkuat lokalitas Kota Semarang di era globalisasi. Penelitian ini dilakukan dengan menggunakan konsep desentralisasi dan paradiplomasi dengan metode kualitatifuntuk menganalisa data yang diperoleh. Penelitian ini menemukan bahwa paradiplomasi tahap pertama telah diterapkan oleh Pemerintah Kota Semarang. Paradiplomasi tahap pertama ini dilakukan untukmencapai kepentingan ekonomi, sepertimeningkatkan investasi dan memperluas pasar, tanpa meninggalkan identitas dan modalitas lokal.
\end{abstract}

Kata kunci: globalisasi, lokalitas, desentralisasi, paradiplomasi

Globalization has caused inter-linkage in every aspect of our life. Decentralization which is strengthened by the proliferation of democratic values through globalization has raised the role of local government in international relations in a phenomenon known as para-diplomacy. Adopting developed countries' experiences, developing countries is now adapting para-diplomacy with their own conditions and interests. This research is aimed to identify the practice of diplomacy which will compatible with the concept of locality, in correlation with the question on how to strengthen locality of Semarang city before the challenge of globalization. This research uses decentralization and para-diplomacy as its conceptual framework with qualitative method to analyze collected data. This research finds that first stage para-diplomacy has been implemented by Semarang government. This first stage para-diplomacy is developed to pursue economic interest, especially to increase investment and expand market, without leaving local identity and modalities.

Keywords: globalization, locality, decentralization, para-diplomacy 
Berakhirnya Perang Dingin telah mengubah sistem internasional, antara lain dalam hal isu dan aktor hubungan internasional. Dewasa ini, Negara tidak hanya berfokus pada isu-isu yang bersifat high politics, namun juga mulai menaruh perhatian pada isu-isu low politics yang secara nyata mengancam keselamatan masyarakat, seperti HIV/AIDS, kejahatan lintas negara, konflik etnis, ataupun pemanasan global. Berkembangnya isu-isu tersebut mendorong terjadinya pergeseran aktor dalam sistem hubungan internasional. Aktor yang dimaksud tidak hanya negara yang sebelumnya memiliki dominasi yang kuat, namun juga melahirkan aktor-aktor baru seperti non-governmental organizations (NGOs) dan multinational corporations (MNCs). Melalui Keputusan Menteri Luar Negeri Republik Indonesia No. 01/B/RO/IV/2015/O1 tentang Rencana Strategis (RENSTRA) Kementerian Luar Negeri, Pemerintah Indonesia merespon positif keterlibatan aktor-aktor lain di luar Negara untuk ikut menyelesaikan permasalahan-permasalahan yang ada. Oleh sebab itu, diplomasi selanjutnya tidak hanya dimaknai sebagai hubungan government to government, tetapi juga hubungan govenment to nongovernment, non-government to non-government, government to people dan people to people. Globalisasi menyebabkan misi dan aktor diplomasi publik mengalami perluasan.

Dalam sebuah negara yang berbentuk kesatuan, dengan sebaran penduduk dan wilayahnya yang luas, menyebabkan pemerintahan Pusat sebagai representasi dari seluruh rakyat dari sebuah negara, akan menjadi tidak berdaya dan tidak efektif-efisien untuk menjangkau dan mengurusi secara langsung beberapa urusan rakyat yang bersifat lokalitas dan jauh dari Pusat. Atas dasar tersebut, diperlukan suatu sistem pemerintahan lokal yang diselenggarakan secara local representative democracy system, dengan menggunakan alat desentralisasi dan otonomi daerah dalam mencapai tujuan. Syarif (2008) dengan mengutip pendapat beberapa ahli, menyebutkan bahwa bagi daerah, desentralisasi dapat mewujudkan political equality, local accountability dan local responsiveness. Dapat disimpulkan bahwa terwujudnya kepentingan daerah terhadap desentralisasi, maka tujuan demokrasi lokal dapat dicapai, yaitu (1) meningkatkan partisipasi publik dalam proses politik, (2) meningkatkan akuntabilitas publik dan (3) meningkatkan kesejahteraan masyarakat.

Semarang sebagai ibukota Jawa Tengah sekaligus merupakan kota terbesar kelima di Indonesia memiliki berbagai keunikan ditinjau dari letak geografi, demografi dan topografi. Secara geografis, Semarang terletak pada posisi 
yang strategis sehingga menjadikan kota ini sebagai lalu lintas ekonomi Pulau Jawa. Kondisi ini menjadi penting dan kekuatan sebagai pusat wilayah nasional bagian tengah dalam rangka hubungan dengan luar Jawa dan luar negeri di era globaisasi yang tidak mengenal batas, ruang dan waktu ini. Ditinjau dari aspek kependudukan, Semarang menjadi salah satu kawasan dengan keanekaragaman suku dan budaya penduduknya. Tidak hanya itu, Semarang juga menawarkan berbagai destinasi pariwisata yang menarik sehingga dapat meningkatkan pendapatan (asli) daerah sebagai penopang pembangunan dan kesejahteraan rakyat di era desentralisasi dengan otonomi yang berprinsip "seluas-luasnya dan bertanggung jawab” yang ditekankan pada Era Reformasi ini. Atas dasar keunikan dan keberagaman yang dimiliki, Semarang memiliki beragam nama yang cukup menarik serta layak dan marketable untuk "dijual", seperti Venice Van Java, The Port of Java, Beauty of Asia, Little Netherland, Kota ATLAS, Kota Lumpia, dan Kota Jamu.

Namun seperti halnya kota-kota besar lain di Indonesia, Semarang juga menghadapi berbagai permasalahan, seperti banjir, penurunan kualitas air tanah, timbunan sampah, tercemarnya air sungai oleh limbah industri, serta buruknya kondisi jalan yang menghubungkan jalur utama. Untuk itu, pemerintah daerah juga perlu menjalin kerja sama dengan berbagai aktor membantu memenuhi kebutuhan masyarakat di wilayahnya, termasuk dengan aktor luar negeri. Provinsi Jawa Tengah sendiri telah memiliki beberapa kerja sama internasional yang sifatnya antar provinsi, antara lain dengan Provinsi Fujian, Republik Rakyat Tiongkok, di mana kerja sama ini sudah terjalin relatif cukup lama. Dalam skema kerja sama yang lebih kecil, tiga kabupaten dan kota di Provinsi Jawa Tengah sudah memiliki kerja sama sister city, yakni Semarang, Surakarta, dan Bumiayu. Dalam era globalisasi seperti saat ini, kota-kota besar seperti Semarang memiliki tanggung jawab untuk mempertahankan lokalitas seiring dengan berubahnya zaman. Di sisi lain, guna meningkatkan kapasitasnya dan juga dengan pertimbangan aspek efisiensi, Kota perlu mencari mitra luar negeri yang dapat diajak bekerjasama. Kerja sama yang dimaksud dapat diimplementasikan melalui paradiplomasi dengan tujuan untuk memperkuat lokalitas Kota Semarang.

\section{Lokalitas Kota Semarang sebagai Modal Paradiplomasi}

Konsep lokalitas lekat kaitannya dengan tempat atau wilayah yang memiliki 
karakteristik tersendiri. Dalam konteks ini, lokalitas Kota Semarang dapat dikatakan sebagai unsur-unsur pembentuk karakter sebagai identifikasi yang membedakannya dengan wilayah lain, yang merupakan interaksi dinamis antara unsur statis berupa geografis setempat, yang kemudian memberikan pengaruh pada unsur-unsur dinamisnya seperti sosialbudaya, ekonomi, dan politik.

Kota Semarang yang secara geografis terletak di pesisir utara Pulau Jawa merupakan pintu perdagangan sehingga secara historis memiliki posisi penting dalam perkembangan budaya lokal. Interaksi antara kelompok pendatang dan penduduk asli menjadikan Kota Semarang sebagai melting pot budaya Jawa, Arab, Cina, dan Belanda. Jejak akulturasi dan asimilasi budaya tersebut masih dapat ditemukan di Kota Semarang, misalnya dalam bentuk arsitektur, seni batik, hingga kuliner. Akulturasi antara budaya Cina dan Jawa menjadi pengaruh dominan dalam pembentukan karakter budaya Semarangan. Hal ini dapat dilihat dari kuliner kota Semarang, seperti loempia (lumpia), kue moci, wingko babad, hingga lontong cap go meh. Tidak hanya itu, akulturasi antara budaya Jawa dan Cina (juga budaya Arab) juga dapat dilihat dari pergelaran seni "Warak Ngendhog" serta bidang arsitektur yang direpresentasikan melalui Kuil Sam Poo Kong dan Kampung Pecinan.

Selain Etnis Cina, Kota Semarang sebagai melting potjuga mempertemukan budaya Barat yang dibawa oleh pendudukan kolonial Belanda dengan budaya lokal. Meskipun demikian, jejak interaksi antar kedua budaya tersebut lebih bersifat asimilasi dibandingkan akulturasi. Hal ini dapat ditelusuri jejaknya dari segregasi antar ras yang diberlakukan oleh pemerintah kolonial antara bangsa kulit putih, pribumi, dan bangsa lainnya (termasuk di dalamnya Etnis Cina dan Arab), yang diciptakan dalam stratifikasi sosial masyarakat untuk membatasi interaksi antar kelompok. Pembatasan itu sendiri dimaksudkan untuk menjaga kemurnian budaya kolonial yang pada masa itu berfungsi sebagai instrumen hegemoni. Fungsi yang demikian dapat dilihat dari digunakannya gaya-gaya arsitektur Belanda dalam bangunan-bangunan simbol kekuasaan.

Dari pemaparan tersebut, dapat diketahui bahwa asimilasi dan akulturasi yang hanya mungkin terjadi karena faktor geografis tersebut telah membentuk ciri budaya lokal yang membedakannya, termasuk dengan wilayah sekitar yang nantinya dikenal sebagai hinterland Kota Semarang. Proses budaya yang terjadi nantinya mampu menjadi salah satu modalitas sosial-budaya dalam paradiplomasi yang dilakukan oleh pemerintah 
maupun pihak-pihak lain dalam konteks mempromosikan Kota Semarang di level global. Modalitas sosial-budaya yang merupakan nilai-nilai budaya ini nantinya mampu menjadi kemasan romantisme atas modalitas ekonomi, yang merefleksikan nilai-nilai komersial. Modalitas ekonomi lokal Kota Semarang juga dipengaruhi oleh kondisi geografis, tidak hanya terkait tipologi yang mempengaruhi tipe aktifitas ekonomi yang dapat dijalankan, tetapi juga persebaran demografi yang nantinya mendorong perubahan strategi pengembangan kota dengan mengintegrasikan wilayahwilayah sekitarnya yang termasuk dalam hinterland Kota Semarang.

Dari aspek historis, sebagai kota yang tumbuh dan berkembang sebagai kota pelabuhan sejak era kerajaan Hindu-Buddha dan semakin ditegaskan fungsinya di era pendudukan Pemerintah Kolonial Belanda, Kota Semarang lebih banyak mengembangkan infrastruktur penunjang aktifitas ekonomi berbasis jasa dengan rancangan tata ruang kota yang juga dibuat berdasarkan tujuan tersebut. Sebagai pusat perdagangan dan pemerintahan Jawa Tengah, Kota Semarang hanya memiliki jumlah lahan yang terbatas di daerah rural untuk dipertahankan sebagai lahan pertanian guna menunjang kehidupan di wilayah kota. Dalam perkembangannya, fungsi penunjang yang dimiliki oleh wilayah rural tersebut didorong lebih jauh beberapa wilayah sekitar seperti Kabupaten Kendal, Kabupaten Demak, Kabupaten Salatiga, dan Kabupaten Grobogan (Kedungsepur) sebagai hinterland dari Kota Semarang (Pemerintah Kota Semarang 2014, 2), sementara wilayahnya sendiri lebih banyak yang difungsikan sebagai pusat administrasi dan bisnis.

Dengan labelnya sebagai kota investasi dan perdagangan, lahan yang ada di Kota Semarang lebih banyak diperuntukkan sebagai kawasan industri seperti Taman Industri BSB, Kawasan Industri Candi, BSB Bonded Zone, Kawasan Industri Wijayakusuma, Kawasan Industri Tugu Wijayakusuma (Seputar Semarang n.d.), Kawasan Industri Terboyo, Kawasan Industri Lamicitra Nusantara, dan Kawasan Industri Bukit Semarang Baru. Tingginya arus investasi yang masuk ke Kota Semarang dalam dekade terakhir membuat kawasan industri dengan luas total 1.029 ha ini sudah penuh (Lazuardi 2014) sehingga dalam pembuatan kebijakan pembangunan, Pemerintah Kota mulai mendorong pembangunan kawasan industri di wilayah hinterland sekitarnya.

Banyaknya kawasan industri yang telah berkembang di Kota Semarang ini kemudian menjadi modalitas tersendiri karena telah tersedianya suprastruktur dan infrastruktur penunjang kegiatan ekonomi yang 
meliputi investasi, produksi, distribusi, dan konsumsi yang memadai. Terintegrasinya aktifitas ekonomi dari hulu ke hilir ini selanjutnya menjadi modal penting bagi Pemerintah Kota Semarang dalam mengembangkan paradiplomasinya, yang kemudian dikemas dalam paket kebijakan pembangunan berbasis Meetings, Incentives, Conferences, and Events (MICE) yang dikemas dengan romantisme budaya yang dimiliki sebagai bentuk modalitas sosial-budaya Kota Semarang.

Meetings, Incentives, Conferences, and Events (MICE) atau business event merupakan jenis pariwisata yang memadukan antara keperluan bisnis dan wisata untuk kesenangan. MICE memberikan keuntungan yang lebih besar daripada wisata untuk kesenangan. Pertama, pengeluaran rata-rata per orang untuk aktifitas MICE lebih tinggi daripada pengeluaran wisata untuk kesenangan. Kedua, sebagian besar pengeluaran tersebut lebih banyak terserap untuk biaya komoditas pertemuan seperti sewa tempat dan biaya organisasi, yang berarti bahwa kemungkinan memperoleh keuntungan dari added value lebih tinggi daripada jika sebagian besar hanya digunakan untuk transportasi dan makanan. Ketiga, industri wisata berbasis MICE tidak mengenal musim sehingga keuntungan dapat dioptimalkan sepanjang tahun (Thailand Convention and Exhibition Bureau 2015).

Pemilihan program MICE dilatarbelakangi oleh dua faktor. Pertama, kehidupan ekonomi Kota Semarang lebih banyak didominasi oleh aktifitas bisnis perdagangan dengan delapan kawasan industri aktif yang tersebar di berbagai wilayah. Banyaknya perusahaan di Semarang tentunya juga berimplikasi pada kuantitas acara bisnis yang diselenggarakan oleh perusahaan-perusahaan tersebut. Kedua, pusat atraksi dari aktifitas MICE adalah acara bisnis yang diselenggarakan, dengan wisata kesenangan sebagai nilai tambah dari paket yang ditawarkan. Dengan fokus yang lebih banyak tertuju pada keikutsertaan di dalam acara bisnis, dapat mengkompensasi minimnya destinasi pariwisata unggulan yang belum dikelola dengan baik. Sementara menjual keunggulan komparatif di sisi pelayanan penyelenggaraan acara bisnis, pemasukan yang diperoleh serta investasi yang masuk dapat dimanfaatkan untuk merevitalisasi objekobjek wisata unggulan Kota Semarang.

\section{Upaya Pemerintah Kota Semarang untuk Memperkuat Lokalitas}


Sebagai bentuk realisasi, Pemerintah Kota Semarang mencanangkan program "Semarang Pesona Asia (SPA)" pada tahun 2007 untuk mempromosikan dan membangun citra Kota Semarang di level nasional maupun internasional guna mendorong pembangunan ekonomi dan pariwisata lokal. Program ini memiliki tiga kegiatan pokok, yaitu kepariwisataan, forum bisnis pengusaha, serta festival atau pameran. Kegiatan kepariwisataan dilakukan dengan melakukan revitalisasi terhadap objek-objek wisata yang mengangkat budaya lokal, seperti Kelenteng Sam Poo Kong, Kawasan Gang Baru, Kawasan Kota Lama, Gedung Lawang Sewu, dan Masjid Agung Jawa Tengah. Selain itu, pemerintah juga berupaya menghidupkan kesenian lokal melalui kegiatan festival, seperti festival Masjid Agung Jawa Tengah dan festival Sam Poo Kong (Kementerian Sekretariat Negara 2007). Selanjutnya, pemerintah mengadakan forum bisnis pengusaha guna mempromosikan Kota Semarang (dan sekitarnya) kepada investor melalui acara tahunan yang dikenal sebagai Semarang Business Forum (Sem’Biz). Dalam perkembangannya, Sem'Biz tidak hanya menjadi forum promosi investasi tetapi juga mengajak kawasan hinterland yang dikenal dengan sebutan Kedungsepur (Pemerintah Kota Semarang 2014).

Selanjutnya, forum Sem'Biz yang mempertemukan stakeholders bisnis dan investasi mulai dari unsur pemerintah kota/kabupaten, instansi penanaman modal kabupaten/kota, pelaku usaha (investor), asosiasi pengusaha/profesi, lembaga keuangan, BUMN dan BUMD menghasilkan LoI sebagai bukti komitmen para investor untuk menanamkan modalnya di Kota Semarang dan sekitarnya (Pemerintah Kota Semarang 2014). Luaran forum dalam bentuk LoI tersebut yang kemudian menjadi parameter untuk melihat keefektifan Sem'Biz dalam mempromosikan perekonomian Greater Semarang yang berbasis potensi lokal.

Dikaitkan dengan potensi lokal sebagai daya tarik investasi dalam Sem'Biz, sebagaimana disampaikan oleh Sita Dewi Pardhihastiwi, koordinator pelaksana Sem'Biz di Badan Pelayanan Perizinan Terpadu', Kota Semarang secara aktif mempromosikan potensi investasi properti terutama untuk revitalisasi kawasan Kota Lama. Penawaran tersebut dilakukan karena banyak potensi properti yang terbengkalai sementara pemerintah kota tidak memiliki cukup anggaran untuk mengelolanya. Hal ini senada dengan temuan Setiadi dan Ma'arif (2009) mengenai isu utama Kota Semarang yang salah satunya adalah banyaknya aset bangunan tua bersejarah yang tidak terawat.

1 Wawancara dilakukan di Badan Pelayanan Perizinan Terpadu Kota Semarang pada hari Rabu, 26 Oktober 2016. 
Padahal di sisi lain, revitalisasi bangunan di kawasan Kota Lama merupakan salah satu program yang harus diselesaikan jika pemerintah Kota Semarang memang berkomitmen membangun citra sebagai kota MICE. Kawasan Kota Lama dapat menjadi destinasi wisata pelengkap business event yang berlangsung, di mana nilai jualnya yang paling tinggi adalah kemasan romantisme historis yang merupakan salah satu modal sosial-kultural utama yang dimiliki oleh Kota Semarang. Meskipun demikian, Sita menyatakan bahwa nyatanya sulit untuk menarik minat investor untuk memasuki sektor ini karena rumitnya prosedur perizinan yang harus dimiliki sebelum investasi bisa ditanamkan.

Namun demikian, Sem'Biz dapat dikatakan berhasil mendatangkan investasi dalam kerangka pembangunan industri MICE. Selain sektor properti historis, Pemerintah Kota Semarang secara agresif membuka peluang investasi properti dalam bentuk hotel, hunian, maupun kawasan perkantoran terpadu. Sebagai contoh, dalam Sem'Biz tahun 2014, investasi yang terkumpul untuk bidang properti tersebut nilainya mencapai Rp 2,93 triliun, lebih dari setengah dari total investasi yang diterima Kota Semarang yaitu sebesar Rp 4,907 triliun (Pemerintah Kota Semarang 2014).

\section{Paradiplomasi Pemerintah Kota Semarang}

Dalam perkembangannya, tren demokratisasi yang membawa ide tentang desentralisasi mendorong peran yang semakin besar dari provinsi, sebagai unit pemerintahan di bawah negara. Fenomena yang oleh Rodrigo Tavares (2016) disebut sebagai "desentralisasi kerjasama (internasional)" ini memunculkan kemungkinan akan terjadinya diplomasi yang dilakukan juga oleh aktor-aktor di bawah negara, termasuk di antaranya adalah pemerintah daerah. Meskipun terdapat keleluasaan yang lebih besar dalam tata kelola pemerintahan daerah, UU No. 23 Tahun 2014 Pasal 10 Ayat 1 menjadi batasan independensi pemerintah daerah dalam konteks desentralisasi kerjasama di level global, karena kekuasaan dalam politik luar negeri masih menjadi otoritas absolut pemerintah pusat (Fathun 2016, 80).

Meskipun demikian, UU No. 37 Tahun 19991999 tentang Tata Cara Hubungan Luar Negeri, UU No. 24 Tahun 2000 tentang Perjanjian Internasional, Peraturan Menlu RI No. 09/A/KP/XII/2006, Permendag No. 3 Tahun 2008, Permendag No. 74 Tahun 2012 dapat menjadi landasan legal dan teknis pemerintah daerah dalam menjalin hubungan transnasional dengan aktor-aktor global lainnya. Berdasarkan wewenang terbatas yang dimiliki, pemerintah daerah dapat membuat dokumen legal yang berfungsi sebagai landasan kerjasama global dalam bentuk Memorandum of Understanding atau Letter of Intent (LoI) (Fathun 2016, 
81). Selanjutnya, berkembang istilah-istilah sebagai upaya konseptualisasi fenomena kontemporer berupa hubungan yang dijalin oleh aktor-aktor sub-negara di level global, termasuk istilah paradiplomasi.

Paradiplomasi yang juga dikenal sebagai diplomasi lokal atau city diplomacy adalah diplomasi yang dilakukan oleh pemerintah daerah dengan aktor-aktor internasional lainnya, dimana tujuannya adalah untuk mencapai kepentingan daerah (van der Pluijm \& Melissen 2007, 6). Warga negara tidak dapat disebut sebagai aktor dari diplomasi lokal, kecuali tergabung dalam gerakan sosial yang memang mewakili kota secara keseluruhan. Berdasarkan definisi tersebut, diplomasi lokal dapat juga dianggap sebagai salah satu bentuk desentralisasi pengelolaan hubungan internasional, karena Kota adalah aktor utamanya. Secara lebih spesifik, diplomasi lokal menekankan pada aktor yang melakukan diplomasi, sementara paradiplomasi menitiberatkan fokus pada relasi paralelnya ${ }^{2}$ dengan diplomasi konvensional.

Dengan mengambil fokus kepada relasi, selanjutnya tulisan ini menggunakan definisi yang disampaikan oleh A. Kuznetsov (2015), yang menyatakan bahwa paradiplomasi adalah "a form of political communication for reaching economic, cultural, political, or any other types of benefits, the core of which consists in self-sustained actions of regional governments with foreign governmental and non- governmental actors". Dalam definisi tersebut, dapat dipahami bahwa terdapat tujuan dari dilakukannya paradiplomasi, yaitu perolehan ekonomi, politik, atau keuntungan yang lainnya. Hal ini berkorelasi dengan layers of paradiplomacy yang ditawarkan oleh André Lecours (2008).

Lapisan pertama berkaitan dengan isu ekonomi, di mana pemerintah subnegara bertujuan untuk membangun eksistensi internasional dalam rangka menarik investasi dan perusahaan asing serta membuka pasar ekspor yang baru. Tidak ada tujuan yang lain dari paradiplomasi lapis pertama ini selain fungsi kompetisi ekonomi global. Lapisan kedua dari paradiplomasi merupakan aktifitas komunikasi yang lebih intens dari lapis pertama, di mana interaksi yang terjalin tidak lagi hanya sebatas fungsi ekonomi tetapi juga telah merambah ke kerjasama untuk peningkatan hubungan people to people di level akar rumput dalam bidang budaya, pendidikan, teknologi, dll. Lapisan ketiga dari paradiplomasi memiliki tujuan politik

\footnotetext{
2 Istilah "paradiplomasi" sendiri muncul pertama kalinya pada tahun 1980-an dalam tulisan Ivo Duchaek dan Panayotis Soldatos yang menggabungkani kata "parallel" dan "diplomacy". (Tavares 2016, 7)
} 
dengan mengadvokasi identitas lokal di level internasional, yang mungkin berbeda dengan persepsi hasil konstruksi pemerintah pusat. Dalam konteks ini, pemerintah sub-negara mencoba membangun hubungan internasional yang dapat mendukung perbedaan budaya, otonomi politik, serta karakter dari komunitas yang diwakilinya (Lecours 2008, 2-4).

Berdasarkan penjabaran di atas, dapat disimpulkan bahwa tujuan utama paradiplomasi adalah menarik perhatian masyarakat global terhadap keunikan region sehinga layak untuk dimasukkan dalam peta global. Paradiplomasi berupaya mengubah terra incognita menjadi tempat yang menarik dengan potensi maupun permasalahan yang dimilikinya (Sergunin \& Joenniemi 2014, 1). Meskipun demikian, meningkatnya paradiplomasi yang difasilitasi oleh kemajuan pesat di bidang teknologi komunikasi dan transportasi juga memunculkan permasalahannya tersendiri.

Semakin banyak pemerintah sub-negara yang memotong jalur diplomasi tradisional dapat menimbulkan permasalahan vertikal maupun horizontal. Salah satu permasalahan dengan dimensi horizontal adalah timbulnya noise dalam arena diplomasi global, di mana semakin banyak aktor yang masuk dengan segala macam proposal, semakin banyak informasi yang beredar sehingga sulit untuk fokus dalam memilih region mana yang benar-benar prospektif dalam mewujudkan tujuan awal dilakukannya paradiplomasi. Di sisi lain, pemerintah sub-negara perlu efisien dalam memanfaatkan sumber daya yang terbatas sehingga perencanaan stategis harus dilakukan jika tidak mau paradiplomasi yang dilakukan hanya berhenti di tahap seremonial. Oleh karena itu, pemerintah sub-negara selain perlu menyiapkan proposal kerja sama yang memahami dan menonjolkan keunikan potensi lokal, juga perlu berpikir strategis dalam mencari partner.

Menyadari pentingnya paradiplomasi bagi kemajuan daerah di era globalisasi, pemerintah Kota Semarang tidak dapat memungkiri urgensi memperkuat modalitas-modalitas lokal sebagai modal utama dalam mempromosikan wilayahnya di arena global. Kesadaran akan peluang akses komunikasi yang dibuka melalui arus globalisasi dan pemahaman akan potensi lokal Kota Semarang yang berdiri dan berkembang sebagai pusat bisnis perdagangan mendorong munculnya skema kebijakan publik yang berbasis pada MICE, dengan Sem'Biz sebagai salah satu program pendukungnya.

Meskipun belum sepenuhnya menyasar partner-partner global, Sem'Biz telah memiliki kerangka yang mencukupi untuk dijadikan metode paradiplomasi bagi pemerintah Kota Semarang (dan sekitarnya). Sebagaimana tujuan besar dari paradiplomasi itu sendiri, yaitu membuat terra incognita agar masuk dalam radar global, Sem'Biz telah menjadi 
prototipe bagi metode yang efektif karena mampu menempatkan serta mengokohkan posisi Kota Semarang dan Greater Semarang dalam peta bisnis nasional. Nilai investasi yang masuk dari investor-investor nasional dan pergerakan ekonomi yang mengikutinya menjadi bukti nyata atas keefektifan komunikasi yang dilakukan antar stakeholders. Dalam forum tersebut juga, masing-masing pemerintah kota/kabupaten telah mampu mengidentifikasi potensi lokal yang layak ditawarkan kepada kalangan investor.

Pada kenyataannya Pemerintah Kota Semarang juga tidak dapat mempromosikan wilayahnya sendirikarena padakehidupan perekonomian di wilayah tersebut didukung oleh wilayah penyangganya (hinterland) yang termasuk dalam Karesidenan Semarang, yaitu Kabupaten Demak, Kabupaten Grobogan, Kabupaten Semarang, dan Kota Salatiga atau lebih dikenal dengan istilah "Kedungsepur". Inklusi wilayah Kedungsepur dalam forum Sem'Biz dilatarbelakangi setidaknya oleh dua alasan. Pertama, wilayah hub tidak akan berkembang tanpa ada wilayah yang menjadi spoke, demikian juga sebaliknya. Pemahaman akan posisi strategis Kota Semarang sebagai pengungkit investasi di region terefleksikan dalam visi Sem'Biz, yaitu menjadikan kota tersebut sebagai trendmark investment policy di Jawa Tengah (Pemerintah Kota Semarang 2014). Kedua, daya tarik bagi investor untuk bergabung dalam forum ini juga akan lebih tinggi jika yang ditawarkan tidak hanya kesempatan berinvestasi di Kota Semarang saja, melainkan kawasan Greater Semarang yang telah terintegrasi dengan baik, minimal dari sisi infrastruktur penunjang industri.

Selanjutnya, forum Sem'Biz yang mempertemukan stakeholders bisnis dan investasi mulai dari unsur pemerintah kota/kabupaten, instansi penanaman modal kabupaten/kota, pelaku usaha (investor), asosiasi pengusaha/profesi, lembaga keuangan, BUMN dan BUMD menghasilkan Letter of Intent (LoI) sebagai bukti komitmen para investor untuk menanamkan modalnya di Kota Semarang dan sekitarnya (Pemerintah Kota Semarang, 2014). Luaran forum dalam bentuk LoI tersebut yang kemudian menjadi parameter untuk melihat keefektifan Sem'Biz dalam mempromosikan perekonomian Greater Semarang yang berbasis potensi lokal.

Meskipun belum sepenuhnya menyasar partner-partner global, Sem'Biz telah memiliki kerangka yang mencukupi untuk dijadikan metode paradiplomasi bagi pemerintah Kota Semarang (dan sekitarnya). Sem'Biz telah menjadi prototipe bagi metode yang efektif karena mampu menempatkan serta mengokohkan posisi Kota Semarang dan Greater Semarang dalam peta bisnis nasional. Nilai investasi yang masuk dari investor-investor nasional dan pergerakan ekonomi yang mengikutinya menjadi bukti nyata atas keefektifan komunikasi yang dilakukan antar 
stakeholders. Dalam forum tersebut juga, masing-masing pemerintah kota/kabupaten telah mampu mengidentifikasi potensi lokal yang layak ditawarkan kepada kalangan investor.

Dengan menggunakan UU No. 37 Tahun 19991999 tentang Tata Cara Hubungan Luar Negeri, UU No. 24 Tahun 2000 tentang Perjanjian Internasional, Peraturan Menlu RI No. 09/A/KP/XII/2006, Permendag No. 3 Tahun 2008, serta Permendag No. 74 Tahun 2012, Pemerintah Kota Semarang dapat membuat MoU atau LoI untuk menangkap akses dan peluang yang ditawarkan globalisasi dalam kerangka paradiplomasi. Praktik tersebut nyatanya sudah dilakukan dalam Sem'Biz dengan menerbitkan LoI atas perjanjian investasi yang disepakati oleh pihak-pihak terkait. Dari LoI yang disepakati, Kota Semarang memperoleh keuntungan ekonomi berupa arus modal yang masuk guna membangun perekonomian lokal. Dari pergerakan aktifitas ekonomi tersebut, selanjutnya pemerintah dapat memenuhi kewajibannya mulai dari penyediaan lapangan pekerjaan yang layak, perbaikan fasilitas perkotaan, hingga peningkatan kualitas pelayanan kesejahteraan sosial bagi masyarakat sebagai dampak dari peningkatan pendapatan asli daerah.

Dalam konteks ini, Sem'Biz sebagai prototipe paradiplomasi Kota Semarang telah menunjukkan bahwa desentralisasi kerjasama (nantinya diharapkan menjadi kerjasama internasional) mampu melengkapi diplomasi pemerintah pusat dalam mempromosikan potensi lokal untuk kegiatan bisnis dan investasi bagi para investor asing. Kemunculan aktoraktor sub-negara tidak saja menawarkan ketersediaan informasi potensi lokal yang memadai, tetapi juga mampu memberikan pemahaman akan permasalahan yang sebenarnya terjadi di daerah.

Dengan kata lain, prototipe paradiplomasi melalui Sem'Biz merupakan apa yang disebut Lecours sebagai paradiplomasi lapis pertama yang berfokus pada utilitas dalam kompetisi ekonomi. Dikaitkan dengan visi Sem'Biz yang berupaya menjadikan Kota Semarang sebagai trendmark investment policy di Jawa Tengah, maka aktifitas diplomasi yang nantinya berlangsung hanya akan menyasar keterpenuhan kepentingan ekonomi daerah dalam bentuk investasi guna menyelesaikan permasalahan berupa keterbatasan kemampuan akumulasi kapital di level region bahkan nasional. Akumulasi kapital ini menjadi penting untuk disolusikan karena kunci dari pengembangan potensi lokal adalah dengan memiliki ketercukupan modal finansial. Diharapkan dengan memiliki kecukupan modal dalam pembangunan, Kota Semarang tidak akan jauh tertinggal dengan ibu kota provinsi lain di Pulau Jawa sehingga sebenar-benarnya dapat merealisasikan slogan "Semarang Setara".

Permasalahan seperti dalam kasus pengelolaan aset-aset properti bernilai 
historis di Kota Semarang menjadi salah satu contoh signifikansi (para) diplomasi yang baik dengan partner-partner global. Dalam kasus ini, terdapat nilai-nilai sosial-budaya lokal yang dapat diadvokasi guna menumbuhkan sentimen, misalnya dengan menggunakan justifikasi konservasi cagar budaya atau arsitektur bersejarah. Dua justifikasi tersebut masih sulit untuk diadvokasi di level nasional, oleh karena itu globalisasi yang menawarkan akses komunikasi langsung dengan aktor-aktor global merupakan alternatif yang paling memungkinkan untuk menjadi solusi dalam kasus ini.

Kota Semarang telah memiliki dua modal utama dalam membangun paradiplomasinya, yaitu sosial budaya dan ekonomi. Modal sosial-budaya berupa identitas kultural sebagai kota melting pot yang mengalami akulturasi dan asimilasi dengan budaya pendatang. Modal ini sudah dapat menjadi atraksi untuk pengembangan industri pariwisata berorientasi MICE yang dikembangkan oleh Pemerintah Kota Semarang. Selain itu, nilai-nilai historis dan budaya yang terendogensiasi dalam tangible maupun intangible culture mampu menjadi romantisme yang mampu menumbuhkan sentimen dari aktor-aktor partner paradiplomasi karena adanya ikatan kultur dalam konteks diaspora maupun keselarasan pemahaman akan nilai-nilai universal yang perlu dipertahankan.

Sementara, modalitas ekonomi berkenaan dengan potensi-potensi lokal, berupa sumber daya alam maupun non-sumber daya alam yang bernilai ekonomis sebagai bagian dari trade-off negosiasi paradiplomasi yang dilakukan. Di satu sisi, pemerintah Kota Semarang dan sekitarnya membutuhkan investasi yang nyatanya hanya dapat diperoleh dari luar wilayah mereka. Dengan adanya globalisasi yang membuka peluang terjalinnya kontak langsung dengan aktor-aktor negara maupun subnegara di belahan dunia lain dapat menjadi alternatif sumber investasi, bahkan dengan kekuatan kapital yang lebih besar daripada hanya mengandalkan akumulasi kapital dalam negeri. Di sisi yang lain, partner potensial ini harus mendapat jaminan bahwa potensi lokal yang ditawarkan juga memiliki prospek profitablitilas yang sesuai dengan resiko investasi.

\section{Simpulan}

Paradiplomasi yang dijalankan oleh suatu entitas politik sub-negara memiliki tujuan yang berbeda-beda, mulai dari ketercapaian kepentingan ekonomi, promosi identitas, hingga pengakuan eksistensi dalam konteks kemerdekaan. Meskipun demikian, ketiganya memiliki tujuan yang sama, yaitu menarik perhatian internasional kepada terra incognita, baik karena potensi maupun permasalahannya. Terkait dengan konsepsi ini, paradiplomasi memiliki fungsi yang koheren dengan upaya penguatan 
lokalitas di tengah globalisasi. Proliferasi nilai, norma, dan budaya yang dianggap sebagai universal mendorong homogenisasi mayoritas, di mana konsekuensinya termasuk mengecilkan atau bahkan menghilangkan lokalitas yang ada.

Sebagai ibu kota provinsi, Semarang memiliki lokalitas yang dapat dijadikan sebagai salah satu langkah paling tepat dalam memajukan kota. Lokalitas yang dimiliki menjadi modalitas pemerintah kota dalam merumuskan garis besar kebijakan pengembangan paradiplomasi, yang salah satunya dapat ditemukan dalam program Semarang Pesona Asia (SPA) dan Sem Biz menjadi prototipe paradiplomasi lapisan ekonomi. Paradiplomasi melalui dua program tersebut memberikan ruang bagi para pemangku kepentingan lokal untuk muncul dan mengejar kepentingannya dengan menjalin jejaring di level internasional, yang utamanya masih berorientasi pada peningkatan investasi dan ekspansi pasar ekspor.

Prototipe sebagai model pertama dari paradiplomasi Kota Semarang ini masih dapat dikembangkan lagi di masa mendatang untuk mengoptimalkan fungsi diplomasi dalam mempromosikan identitas dan kepentingan lokal, yang mana tentunya tidak lepas dari lokalitas itu sendiri. Pekerjaan yang selanjutnya perlu diselesaikan oleh Pemerintah Kota Semarang sebagai pemegang kekuasaan tertinggi dalam rangka mengembangkan paradiplomasi adalah meningkatkan kesiapan potensi serta pemilihan partner paradiplomasi yang relevan, sehingga program-program yang dijalankan dapat tepat sasaran dan memiliki peluang keberhasilan yang tinggi.

\section{Referensi}

\section{Buku dan Bab dalam Buku}

Kuznetsov, A.S., 2015. Theory and Practice of Paradiplomacy: Subnational Governments in International Affairs. New York: Routledge.

Lecours, A., 2008. Political Issues of Paradiplomacy: Lessons from the Developed World. Den Haag: Netherlands Institute of International Relations 'Clingendael'.

Laporan Kegiatan: 8th Semarang Business Forum, 2008. $\quad$ Semarang: Badan Pelayanan Perizinan Terpadu Kota Semarang.

Setiadi, Rukuh, dan Samsul Ma'arif. 2009."Pemetaan Isu dan Permasalahan Utama Pembangunan Kota Semarang dalam Penyelenggaraan 
Pemerintahan." Riptek 25-34.

Tavares, R., 2016. Paradiplomacy: Cities and States as Global Players.

New York: Oxford University Press.

Van der Pluijm, Rogier \& Jan Melissen, 2007. City Diplomacy: The Expanding Role of the Cities in International Politics. Hague:

Netherlands Institute of International Relations.

\section{Jurnal dan Jurnal Daring}

Fathun, L. M., 2016. "Paradiplomasi Menuju Kota Dunia: Studi Kasus Pemerintah Kota Makassar", Indonesian Perspective, 1(1): 75-94.

Hidayat, Syarif., 2008: "Desentralisasi Dan Otonomi Daerah Dalam Perspektif State-Society Relation”, Jurnal POELITIK Vol.1 No.1.

\section{Lain-lain}

Kementerian Sekretariat Negara, 2007.Semarang Pesona Asia 2007Resmi Dibuka. dalam http://www.setneg.go.id/index.php?option=com content\&task=view\&id=667 [diakses pada 20 November 2016].

Lazuardi, H., 2014. Kawasan Industri Kota Semarang Hampir Penuh. dalam http://kabar24.bisnis.com/read/20140508/78/226142/ kawasan-industri-kota-semarang-hampir-penuh diakses pada 29 November 2016].

Seputar Semarang, n.d. Kawasan Industri Semarang. dalam http://seputarsemarang.com/tag/kawasan-industri/ [diakses pada 29 November 2016].

Sergunin, A. \& Joenniemi, P., 2014. Paradiplomacy as a Sustainable Development Strategy: The Case of Russia's Arctic Subnational Actors. Eurasia Border Review, pp. 1-17.

Thailand Convention and Exhibition Bureau, 2015. Introduction to MICE Industry. dalam http://msi.citu.tu.ac.th/uploads/news/ file/20150820/en-bhlmprt01347.pdf [diakses pada 30 November 2016]. 